\title{
AUTOMATION OF MEASUREMENT UNCERTAINTY ASSESSMENT BASED ON CMS MAPLE
}

\author{
I.O. Moshchenko, O.M.Nikitenko \\ Kharkiv national university of radio electronics, Kharkiv, Ukraine, inna.moshchenko@nure.ua
}

\begin{abstract}
Annotation
The problem of studying of the uncertainty theory principles and understanding the relationship between the concepts of uncertainty and error and practical application skills of the determining uncertainty method in the international harmonization pursuit and unification of measurement results evaluation were analyzed.

The estimating uncertainty results by standard methods can be sublimated into tabular form shown as uncertainty budget. To calculate the indicators that make up the uncertainty budget it is necessary to make a model equation of the studying process, to obtain numerical values for standard uncertainties of types A and B, sensitivity coefficients, total standard uncertainty and extended uncertainty. These calculations require specialists in technical specialties, with a high level of mathematical training and a lot of effort and time to solve practical problems for uncertainty assessment when solving a specific engineering problem. Therefore, it is advisable to use computer mathematics systems (CMS) to calculate the measurement uncertainty budget.

Skills possession in working with CMS Maple allows you to algorithmize the estimating measurement uncertainty process. The authors have developed a training program called UC (Uncertainty), which makes it possible to obtain results for budgeting uncertainty in the presence of a model equation of the process and measurement results.

Thus, the using CMS Maple expediency and possibility to solve the problems of applied metrology to assess the measurement results uncertainty are substantiated.
\end{abstract}

Keywords: the uncertainty theory, the uncertainty budget, model equation, measurement uncertainty assessment, automation, CMS Maple, program UC (Uncertainty).

Since 2007 the 1 January according to Order of State Committee for Technical Regulation and Consumer Policy of Ukraine since 11.07.2006 the normative document was came into force DSTU-N RMG 43:2006 Metrology. Application Manual to expression of measurement uncertainty (RMG 43-2001, IDT). In this manual legally enshrined the method of measurement estimation of results' accuracy according to uncertainty theory provisions in metrology.

Last time in metrology both theoretical and experimental essential changes took place. These changes connected at first introducing notion "uncertainty" to estimate the quality of measurement results and measurement instruments.

In "error conception" measurement results' accuracy was determined measurement error. That is measurement result's deviation from real value of measured one [1].

In "uncertainty conception" measurement results' accuracy was determined a measurement uncertainty. This conception based on postulate: measurement result is random variable. As parameter a measurement uncertainty characterized scattering the set of possible values but not certain measurement result's value [2].

Calculation methods of uncertainty such as error estimation methods based on the same mathematical statistics methods. The same for both approaches are and actions' sequences during measurement error and uncertainty calculations [3, 4].

Actual problem today is a lack of understanding the uncertainty principles and the relation between uncertainty and error conceptions by metrology engineers. They have not enough competence of practical applied method expression uncertainty that is a part of the desire to international harmonization and unification of measurement results estimation.

On the other hand the measurement uncertainty assessment needs huge volume calculation and using difficult mathematical operation. To simplify these works it is expedient different computer mathematic systems.

Thus this article purpose is show how we can use computer mathematic system Maple to statistical calculations in general and uncertainty one in particular.

There are many publications described principles of uncertainty theory and accuracy assessment of measurement methods. Using such kind publications metrology engineers and students are studying these theory principles.

In general the process of measurement uncertainty assessment consists a number of steps [5].

1. Specify the Process and Equation

To estimate uncertainty, it is necessary to divide the model equation and evaluate the uncertainty of each variable.

2. Identify and Characterize the Uncertainty Sources

After we know the measurement process, we need to identify the factors that influence uncertainty in measurement results.

3. Quantify the Magnitude of Uncertainty Components

Before calculating measurement uncertainty, we must first determine the magnitude of each contributing factor. To accomplish this, we may need to perform some data reduction and analysis.

Once we have analyzed the data and determined the magnitude of each uncertainty source, we will want to use an uncertainty budget helping to calculate a total expanded uncertainty. Uncertainty budgets are a great tool for organizing the data and demonstrating how we calculated the measurement uncertainty estimation. 
After that we need to reduce each uncertainty contributor to a standard deviation equivalent. This task must be done for each uncertainty contributor that we quantified in step 3.

5. Calculate the Combined Standard Uncertainty

After we have reduced the uncertainty sources to standard deviation equivalents, it is necessary to combine them. To accomplish this, we must use the root sum of squares method or RSS.

6. Calculate the Expanded Uncertainty

On next step, it is necessary to expand a combined uncertainty to an acceptable level of confidence.

7. Evaluate Uncertainty for Appropriateness

Once we have calculated the expanded uncertainty, it is important to evaluate the uncertainty estimation for appropriateness. It gives confidence that measurement uncertainty estimation adequately represents a certain measurement process and it is not overestimated or underestimated.

In this article to simplify the uncertainty assessment it is proposing to use the computer packages. There are many computer packages calculating statistical performances.

Computer Mathematics Systems are effective method to mathematic learning and processing by technical specialists from Europe, USA, Japan, China and other countries. Unfortunately in our education system both students and teachers are known modern computer mathematics systems not enough. It very slowed down solving some problems to implement our education system and technical community in world education ones where computer mathematics systems are in active using.

Publication analysis evidents about intensive investigation on the implementation of information and communication technologies in particular computer oriented education systems.

Choice of Computer Mathematics System dependent on the ultimate goal of tasks class, their appointment.

The main functions of such systems are:

- visual means data presenting (electron reference book with hypertext help system and intuitive interface, animate examples audio and video accompaniment);

- solving practical problems means, complex models research, thorough analysis of solving tasks' variants, development of practical skills of mathematical reasoning.

CMS can be divided into seven classes: systems for numerical calculations; table processors; matrix systems; systems for statistical calculations; systems for special calculations; systems for analytical calculations (computer algebra); universal systems [6].

CMS comparison was shown in table [7].

Compared to other mathematical software packages, CMS Maple has several advantages that are of particular importance when solving statistical applied problems in the field of metrology, namely: possibility of symbolic calculations, operation of numbers with arbitrary accuracy, representation of graphs in dynamic mode, etc [8].

\begin{tabular}{|c|c|c|}
\hline \multicolumn{3}{|c|}{ CMS comparison } \\
\hline CMS & Advantages & Disadvantages \\
\hline Mathematica & $\begin{array}{l}\text { Compatibility with } \\
\text { computer } \\
\text { platforms. } \\
\text { graphics. } \\
\text { Documents } \\
\text { (notebook). Sound } \\
\text { synthesis support. }\end{array}$ & $\begin{array}{l}\text { Excessive copy } \\
\text { protection. } \\
\text { Targeting } \\
\text { experienced users. }\end{array}$ \\
\hline Matlab & $\begin{array}{l}\text { Unique matrix } \\
\text { tools, descriptor } \\
\text { graphics, high } \\
\text { speed calculations, } \\
\text { adaptation to } \\
\text { user's tasks and } \\
\text { number of system } \\
\text { packages. }\end{array}$ & $\begin{array}{l}\text { Limited } \\
\text { opportunities of } \\
\text { symbolic } \\
\text { calculations. } \\
\text { High cost of the } \\
\text { system and their } \\
\text { packages. }\end{array}$ \\
\hline MathCad & $\begin{array}{l}\text { Quality graphics } \\
\text { and visualization } \\
\text { during } \\
\text { calculations. } \\
\text { Comfortable } \\
\text { interface. } \\
\text { Mathematical } \\
\text { signs palette } \\
\text { availability. Huge } \\
\text { choice of electron } \\
\text { books and } \\
\text { libraries, operators } \\
\text { and functions. }\end{array}$ & $\begin{array}{l}\text { Symbolic } \\
\text { mathematic } \\
\text { limitation. } \\
\text { Primitive } \\
\text { programming. Cost } \\
\text { of electron books } \\
\text { and libraries. }\end{array}$ \\
\hline Maple & $\begin{array}{l}\text { Thoughtful kernel } \\
\text { of symbolic } \\
\text { calculations. } \\
\text { Documents } \\
\text { (notebook). High } \\
\text { quality graphics. } \\
\text { Convenient help } \\
\text { system. }\end{array}$ & $\begin{array}{l}\text { No sound } \\
\text { synthesis. }\end{array}$ \\
\hline
\end{tabular}

There are many manuals the metrology students and engineers using the uncertainty theory fundamentals and estimation method of uncertainty theory. Using standard method the estimation of measurement uncertainty we can transform to table form which represented as uncertainty budget [5]. To calculate the factors including to an uncertainty budget students must made a model equation of studying process, obtained numerical values to standard uncertainty A and B types, sensitivity factor (as derivative part of output value from every input values), summary standard uncertainty and expanded uncertainty. Such calculations require from specialists to have a high level of mathematical education and spend a lot of effort and time to solve practical tasks to estimate an uncertainty during to solve specific engineering tasks. Thus it is relevant metrology specialists to use computer mathematical system (CMS) to write an measurement uncertainty budget.

CMS Maple allowed to make algorithm an uncertainty estimation process. The program called UC (Uncertainty) has been developed by authors, allowed to obtain an uncertainty budget results. Input data are 
modeling equation, measuring results (input quantities). This program calculates such values: input values estimate, output values estimate, standard uncertainty, expanded uncertainty.

This program output results are uncertainty budget and graphical illustration of evaluating standard uncertainty.

\section{Conclusion}

Thus it was justified expediency and possibility using CMS Maple to solve applied metrology tasks to estimate measurement results' uncertainty and the importance of learning the metrology students, engineers and the other ones of technical subjects to use UC program for optimisation of metrology tasks solving problems.

\section{Анотація}

Проаналізовано проблему вивчення основ теорії невизначеності, розуміння співвідношення концепцій невизначеності та похибки, та навичок практичного застосування методики визначення невизначеності в рамках прагнення до міжнародної гармонізації та уніфікації оцінювання результатів вимірювань.

Результати оцінювання невизначеності за стандартною методикою можуть бути сублімовані у табличну форму, подану як бюджет невизначеності. Для обчислення показників, які становлять бюджет невизначеності, необхідно скласти модельне рівняння процесу, який досліджують, отримати числові значення для стандартних невизначеносте й типів А і B, коефіцієнтів чутливості, сумарної стандартної невизначеності та наприкінці розширеної невизначеності. Ці розрахунки вимагають від фахівців технічних спеціальностей, володіння високим рівнем математичної підготовки, а також багато зусиль та часу для розв'язання практичних завдань з оцінювання невизначеності під час вирішення конкретної інженерної задачі. Тому доцільним вбачається використання систем комп’ютерної математики (СМК) для складання бюджету невизначеності вимірювань.

Володіння навичками в роботі з СМК Марlе дозволяє алгоритмізувати процес оцінювання невизначеності вимірювання. Авторами розроблено навчальну програму під назвою UC (Uncertainty), яка надає можливість отримувати результати для складання бюджету невизначеності за наявності модельного рівняння процесу та результатів вимірювань.

Таким чином, обгрунтовано доцільність та можливість застосування СМК Марlе для вирішення завдань прикладної метрології з оцінювання невизначеності результатів вимірювання.

Ключові слова: теорія невизначеності, бюджет невизначеності, модельне рівняння, оцінювання невизначеності вимірювання, автоматизація, СКМ Maple, програма UC (Uncertainty).

\section{Аннотация}

Проанализирована проблема изучения основ теории неопределенности, понимания соотношения концепций неопределенности и погрешности и навыков практического применения методики определения неопределенности в рамках движения к международной гармонизации иа унификации оценивания результатов измерений.

Результаты оценивания неопределенності по стандартной методике могут быть сублимированы в табличную форму, представленную как бюджет неопределенности. Для вичисления показателей, которые составляют бюджет неопределенности, необходимо составить модельное уравнение исследуемого процесса, получить числовые значения для стандартних неопределенностей типов А и В, коэффициентов чуствительності, суммарной стандартной неопределенности и в конце расширенной неопределенности. Эти расчеты требуют от специалистов технических специальностей, владения высоким уровнем математической подготовки, а также много усилий и времени для решения практических заданий по оцениаанию неопределенности при решении конкретной инженерной задачи. Поэтому целесообразным выявляется использование систем компьютерной математики (СМК) для составления бюджета неопределенности измерений.

Владение навыками в работе с СМК Maple позволяет алгоритмизировать процесс оценивания неопределенности измерения. Авторами сознана программа под названием (Uncertainty), которая дает возможность получать результаты для составления бюджета неопределенности при наличия модельного уравнения процесса и результатов измерений.

Таким образом, обоснована целесообразность и возможность использования СМК Марlе для решения задачь прикладной метрологии по оцениванию неопределенности результатов измерений.

Ключевые слова: теория неопределенности, бюджет неопределенности, модельное уравнение, оценивание неопределенности измерения, автоматизация, СКM Maple, программа UC (Uncertainty).

\section{References}

1. DSTU 2681-94 Metrology. Terms and definitions (in Ukrainian).

2. DSTU-N RMG 43:2006 Metrology. Using. "Guide to the expression on uncertainty in measurement" (RMG 432001, IDT) (in Russian)

3. RMG 91-2009 GSI. Together using of terms "measurement error" and "measurement uncertainty". Total principles. (in Russian)

4. B.V. Grinev, N.R. Gurjan, O.V. Zelenskaya, V.R. Liubinski N.I. Molchanov, V.A. Tarasov Comparison analysis of calculating error and uncertainty measurement method. On scintillator example. Kharkiv. Metrology-2012. pp. 54 - 60, (in Russian).
5. Evaluation of measurement data - Guide to the expression on uncertainty in measurement - Geneva: ISO, 2010. $122 \mathrm{p}$.

6. Djakonov V.P. Computer mathematics. Sorosovskij obrazovatel'nyj zhurnal, 2001. - vol. 7. (in Russian)

7. Hrybjuk O.O., Yunchyk V.L. Using of computer mathematics systems on context mixing education model. Matematyka. Informatsijni tekhnolohii. Osvita: [zb. statej] / SNU imeni Lesi Ukrajinky. - Luts'k - Svitjaz', 2015. P. $52-71$ (in Ukrainian).

8. Aladjev V. Z. Programming in Maple and Mathematica packages : Comparison aspect] Hrodno, HrSU, 2011. 517 p. (in Russian) 


\section{Список літератури}

1. ДСТУ 2681-94 Метрологія. Терміни та визначення

2. ДСТУ-Н РМГ 43:2006 Метрологія. Застосування. «Руководства по выражению неопределенности измерений» (РМГ 43-2001, IDT).

3. РМГ 91-2009 ГСИ. Совместное использование понятий «погрешность измерения» и «неопределенность измерения». Общие принципы.

4. Б.В. Гринев, Н.Р. Гурджян, О.В. Зеленская, В.Р. Любинский, Н.И. Молчанова, В.А. Тарасов Сравнительный анализ методик вычислений погрешности и неопределенности измерений на примере сцинтиллятора Харків Метрологія-2012 С. 54
5. Evaluation of measurement data - Guide to the expression on uncertainty in measurement - Geneva: ISO, 2010. $122 \mathrm{p}$.

6. Дьяконов В.П. Компьютерная математика. Сросовский образовательный журнал, 2001. - т. 7.

7. Гриб'юк О.О., Юнчик В.Л. Використання систем комп'ютерної математики у контексті моделі змішаного навчання. Математика. Інформаційні технології. Освіта: [зб. статей] / СНУ імені Лесі Українки. - Луцьк - Світязь, 2015. - Р. 52 - 71

8. Аладьев В. 3. Программирование в пакетах Maple и Mathematica : Сравнительный аспект. Гродно, ГрГУ, $2011.517 \mathrm{c}$. 